the history of that industry and of its wonderful development is to be found in the Journal of the Iron and Steel Institute.

No one can doubt that the Institute will continue to go forward and prosper along the same lines traced out for it by its founders, which it has so consistently followed throughout the whole sixty years of its existence, and it seems almost superfluous to wish for a continuance of its prosperity for many years to come. This wish will indeed be fervently re-echoed by everyone in Great Britain, seeing that the prosperity of the Iron and Steel Institute is bound up with the prosperity of the iron and steel industry, which in its turn is the foundation of the prosperity of the nation.

\section{The Stone Age in South-Eastern Asia.}

RECENT research appears to point to more or less 1 uniformity in the characteristics of the stone age cultures of south-eastern Asia. Investigations in French Indo-China by MM. Mansuy and Patte and Mlle. Colani in the caves near the Bac-Son massif (Tonkin) yielded a large number of implements which these investigators regarded as relics of the oldest known stone age of Indo-China, classifying them as lower neolithic. Cord-marked pottery was also found, but regarded as belonging to a later phase of the neolithic. Evidence of similar stone age industries has been found in kitchen middens about twenty kilometres from Medan in the east coast province of Sumatra, and on the plains and lower hills of this province at sites always on the banks of rivers.

In the Journal of the Federated Malay States Museums, vol. 12, Part 6, Mr. I. H. N. Evans reviews this material critically in relation to the results of recent excavations in caves in Perak. The hypothesis of the French archæologists is that an early neolithic people, using roughly chipped implements only, came into contact with a people using polished implements, and from them adopted the practice of polishing the edges of their implements. Mr. Evans, however, regards the chipped implements as a truly older palæolithic culture, surviving in association with the forms with polished edges which are proto-neoliths, the latter developing more and more to become a high neolithic culture. In Sumatra, iron weapons of a type still in use in north Sumatra in a layer immediately above that containing bouchers, with no sign of transition, pointed to a very late survival of a palæolithic culture.

In Perak, Mr. Evans, excavating with Dr. P. U. Van Stein Callenfels, of the Archæological Service of the Netherlands Indies, who carried out the investigations in Sumatra, found similar stone age cultures in caves near Lenggong (Upper Perak) and Padang Rengas (Kuala Kangsar). In the latter area the rock shelter, Gua Kerrbau, contained human remains at a depth of 3.18 metres and below. Shellfish formed a large part of the diet of the inhabitants throughout the occupation. Flakes and chips occurred throughout, but the first palæolith was found in deposit $B$, the most common type being the coup de poing of almond shape. The first fragment of a proto-neolith occurred in layer $D$ at a depth of 2.40 metres. The lowest was found at 5.74 metres. The proto-neoliths showed different stages of development. One might be classified as a middle neolith. Grinding stones, grinding slabs, shells, some clearly, others probably, for use as amulets, and pottery in the upper layer were found.

Certain conclusions are offered tentatively: Palæoliths, so-called Sumatra types, and proto-neoliths, are associated throughout; cord-marked pottery belongs to the later stages of palæo-proto-neolithic culture; the makers of proto-neoliths had older types of the neolithic culture as examples; and a palæolithic civilisation making use of 'Sumatra-type' implements spread at a certain period over south-east Asia, reaching even Sumatra, while the palæo-proto-neolithic stage also spread over the same area but did not reach Sumatra.

\section{University and Educational Intelligence.}

LEEDs.-The site is now being cleared for the new block for the Physics Department. The accommodation will include two large laboratories, each about. 5000 square feet in area, and a smaller laboratory for honours students, three lecture theatres for $\mathbf{2 5 0}$, 150 , and 80 students respectively, and about thirty other rooms, the whole occupying a block about 100 feet square and comprising a basement and three floors over. The building is estimated to cost about $\mathfrak{4} 47,400$.

LoNDON.--Notice is given that applications for grants from the Thomas Smythe Hughes Fund for assisting medical research must reach the Academic Registrar, South Kensington, S.W.7, by, at latest, June 15.

ST. ANDrews.--At a meeting of the University Court on April 19, it was intimated that Provost W. Norman Boase, St. Andrews, had gifted to the United College the endowment fund for the institution of a residential entrance scholarship of $£ 100$ a year, tenable for three or four years by an entrant student resident in one of the residential halls of the United College, on conditions similar to those prescribed in the case of the Harkness, Russell, and Patrick Hamilton Entrance Scholarships. As the Patrick Hamilton Scholarship was instituted in commemoration of the quater-centenary of Patrick Hamilton, the Martyr, a former student of the University, so the new scholarship is to be named the Montrose Scholarship in commemoration of the tercentenary of the studentship at St. Salvator's College of the great Marquis of Montrose.

Applicatrons for grants from the Dixon Fund of the University of London, for assistance in scientific investigations, must reach the Academic Registrar of the University, South Kensington, S.W.7, before May 15.

A Busk Studentship in aeronautics, of the value of about $£ 150$ and tenable for one year from Oct. 1 next, for research in aeronautics and specially in stability problems, is being offered. Forms of application, returnable not later than May 12, can be obtained from Prof. B. Melvill Jones, Engineering Laboratory, Cambridge.

A FELcowship of the value of $£ 300$ per annum for research on petroleum problems is being offered by the Institution of Petroleum Technologists. The fellowship will be tenable for one year, with a possible renewal for a further year. Forms of application (returnable by June 1 at latest) are obtainable from the Secretary of the Institution, Aldine House, Bedford Street, W.C.2.

Applications are invited by the trustees of the Dickinson scholarships in connexion with the Manchester Royal Infirmary and the University of Manchester for the following : A research travelling scholarship in medicine value $£ 300$, and a pathology scholarship value $\mathfrak{E 7 5}$. Particulars may be had from the Secretary to the trustees, Royal Infirmary, Manchester. The completed forms must be returned by May 2.

No. 3104, VoL. 123] 